(c) American Dairy Science Association, 2005.

\title{
Effects of Vegetable Fats Versus Lard in Milk Replacers on Feed Intake, Digestibility, and Growth in Finnish Ayrshire Bull Calves
}

\author{
A. Huuskonen, ${ }^{1}$ H. Khalili, ${ }^{2}$ J. Kiljala, ${ }^{1}$ E. Joki-Tokola, ${ }^{1}$ and J. Nousiainen ${ }^{3}$ \\ ${ }^{1}$ MTT Agrifood Research Finland, North Ostrobothnia Research Station, FIN-92400 Ruukki, Finland \\ ${ }^{2}$ MTT Agrifood Research Finland, Animal Production Research, FIN-31600 Jokioinen, Finland \\ ${ }^{3}$ Valio Ltd., Farm Services, P.O.Box 10, FIN-00039 Valio, Finland
}

\section{ABSTRACT}

The aim was to study whether vegetable fat mixtures could be used instead of lard [15.2\% in dry matter (DM)] in milk replacers without impairing the performance of Finnish Ayrshire bull calves $(n=58)$. The growth performance of the calves was measured before and after weaning from $14 \mathrm{~d}$ to $6 \mathrm{mo}$ of age. The following 3 fat sources in a milk replacer were studied: 1) a mixture of palm, coconut, and rapeseed oil, 2) palm and coconut oil, and 3) lard. The calves were bucket-fed 2 $\mathrm{L}$ of milk replacer 3 times per day. The milk replacer contained $116 \mathrm{~g}$ of DM/L, resulting in an average DM intake of $4.8 \mathrm{~g}$ of $\mathrm{DM} / \mathrm{kg}$ of body weight ${ }^{0.75}\left(\mathrm{BW}^{0.75}\right)$ during the 8-wk trial, after which the calves were weaned. All the calves had free access to water, commercial starter, and grass silage before weaning. The weaned calves had free access to water and grass silage and were given $3 \mathrm{~kg} / \mathrm{d}$ (air-dry basis) of a commercial concentrate mixture. The concentrate was replaced by barley when the bulls were 4.5 mo old. There were no significant differences between the diets in feed intake and apparent diet digestibility. The health and BW of the calves were similar during the study. The feed conversion rate $(\mathrm{kg}$ of $\mathrm{DM}$ intake $/ \mathrm{kg}$ of gain) before weaning was significantly greater for the lard diet compared with the 2 vegetable fat mixtures. After weaning, the feed conversion rate was slightly lower for the diet that included the palm, coconut, and rapeseed oil mixture than for the diet that included palm and coconut oil mixture. The study showed that the 2 mixtures consisting solely of vegetable oils were effective dietary components, thus providing 2 alternative fat mixtures of milk replacers, for use instead of lard in formulating commercial calf milk replacers.

(Key words: calf, fat, milk replacer, performance)

Abbreviation key: $\mathbf{M E}=$ metabolizable energy, $\mathbf{M R}=$ milk replacer, VO1 = a mixture of palm, coconut, and rapeseed oils, $\mathbf{V O 2}=$ a mixture of palm and coconut oils.

Received March 31, 2005.

Accepted June 23, 2005.

Corresponding author: H. Khalili; e-mail: hannele.khalili@mtt.fi.

\section{INTRODUCTION}

Good health and growth performance of nonsuckling dairy and crossbred calves before weaning are important aspects of dairy herd management. Whole milk would be the most natural feed, but due to its high cost, milk replacers (MR) are generally used. According to Heinrichs et al. (1995), nearly $60 \%$ of US dairy farms use MR. Milk fat would be the best fat source in MR for calves because it is nutritionally unique and, compared with other fats, contains a relatively high proportion (15 to $20 \%$ ) of highly digestible medium-chain saturated fatty acids (Raven, 1970). In the United States, MR has typically contained fats mostly from animal sources (lard, tallow, and white grease). Until recently, tallow was used in Finland as the main fat source in MR, but feed manufacturers currently use lard instead of tallow. In other European countries, feed manufacturers are reluctant to use tallow and other animal fats due to public and consumer concern related to bovine spongiform encephalopathy. Although lard may be a suitable fat source in MR, alternative raw materials such as different vegetable fat mixtures may have an increasing role as fat sources in MR especially if consumer perception related to use of animal fats for calf feeding will be debatable. An advanced formulation of MR using inexpensive, alternative fats is a constant challenge for feed manufacturers. Depending on availability and market price, manufacturers may use different fat sources. Thus it is of interest to provide more information concerning calf performance when calves are fed liquid diets in which animal fat sources are replaced by vegetable oils.

Some previous studies have shown variable calf performance when vegetable oils are included in MR. For example, Graulet et al. (2000) reported similar gains for calves fed tallow or coconut oil. Jenkins et al. (1985) observed equivalent performance for tallow and coconut oils but markedly poorer results for corn oil. In contrast, Jenkins (1988) and Jenkins et al. (1986) reported better gains for tallow compared with coconut oil.

There is, however, little data from a single study about the pre- and postweaning performance of dairy 
breed bull calves when the MR fat source is either a mixture of vegetable oils or lard. The aim of this work was to study whether the MR fat source would 1) affect the preweaning performance and weaning weight of bull calves, 2) impose differences in growth rate after weaning until 6 mo of age, and 3) affect feed conversion efficiency pre- and postweaning. The present study comprised 2 experiments in which one animal fat (lard) and 2 mixtures of vegetable oils (mixture of palm, coconut, and rapeseed or palm and coconut oils) were compared as MR fat sources.

\section{MATERIALS AND METHODS}

\section{Animals, Housing, and Diets}

The first experiment started in September 2001 and the second in April 2002. The trials were conducted in the experimental barn of the North Ostrobothnia Research Station of MTT Agrifood Research Finland. Thirty Finnish Ayrshire bull calves were taken into the first experiment at an average age of $14 \mathrm{~d}$ and BW of 47.1 (SE 1.1) kg. The second experiment included 29 Finnish Ayrshire bull calves and one Friesian bull calf at an average age of $14 \mathrm{~d}$ and average BW of 49.3 (SE 1.1) kg. All animals were purchased from local dairy farms (between 15 and $205 \mathrm{~km}$ from the experimental farm) and they were in good condition. In Finland, dairy farms generally have a colostrum feeding program during the first $2 \mathrm{~d}$ after birth: calves are bucketfed 4.5 to $5 \mathrm{~L} / \mathrm{d}$ of colostrum per day (delivered 2 or 3 times per day). Thereafter, calves are generally given about $5 \mathrm{~L}$ of milk/d during the next 11 to $12 \mathrm{~d}$. In both experiments, the animals were housed on peat bedding in 6 pens $(3.0 \times 3.5 \mathrm{~m} ; 5$ calves in each), providing 2.1 $\mathrm{m}^{2} /$ calf. Calves were randomly allotted to pens, which were then randomly allotted to 3 experimental treatments giving 20 bull calves per treatment.

The MR included (\% from DM) skim milk powder (55.8), whey powder (24.5), rapeseed oil (0.9), lard (15.2), wheat starch (2.3), lecithin (0.4), vitamin-mineral premix (0.2), $\mathrm{NaCl}(0.3)$, and $\mathrm{CaCl}_{2}(0.4)$. In the control diet, lard was used as the animal fat source in MR. The other 2 diets contained a mixture of palm (75\%), coconut (20\%), and rapeseed oils (5\%) (VO1), or a mixture of palm (75\%) and coconut oils (25\%) (VO2), representing vegetable mixtures of nonhydrogenated fats in MR. In both experiments, calves were bucketfed $2 \mathrm{~L}$ of $\mathrm{MR}$ (feeding temperature $38^{\circ} \mathrm{C}$ ) 3 times/d $(0630,1200$, and $1800 \mathrm{~h})$. The total daily MR intake was $698 \mathrm{~g}$ of DM, providing $4.8 \mathrm{~g}$ of DM/ $/ \mathrm{kg} \mathrm{BW} \mathrm{BW}^{0.75}$ during the 8 -wk experiment. Thereafter, calves were gradually weaned by giving $2 \mathrm{~L}$ of milk replacer twice a day in wk 9 , and $2 \mathrm{~L}$ of milk replacer once a day in wk 10 . All 3 milk replacers were delivered by Valio Ltd. (Valio,
Finland). Before weaning, calves had free access to water from an open water bowl, commercial pelleted calf starter (12.3 MJ of metabolizable energy (ME)/kg of $\mathrm{DM}$ ), and grass silage (offered from a box feeder with proportional refusals as 5\%). Postweaning, the calves had free access to water and were fed grass silage ad libitum. The amount of concentrate was restricted to 3 $\mathrm{kg} / \mathrm{d}$ (air-dry). The commercial concentrate included (\% of DM) barley (18.0), oats (13.0), wheat bran (11.0), rapeseed meal (9.5), rapeseed cake (8.0), molassed sugar-beet pulp (8.0), wheat (5.0\%), wheat syrup (5.0), wheat feed meal (4.6), soybean meal (4.0), distilled solubles (4.0), malted sprouted barley (5.5), vegetable oil (0.2), and minerals and vitamins (4.2). It contained 891 $\mathrm{g}$ of DM/kg; CP, $209 \mathrm{~g} / \mathrm{kg}$ of DM; NDF, $265 \mathrm{~g} / \mathrm{kg}$ of DM, and 12.3 MJ of ME/kg of DM (Raisio Nutrition Ltd., Raisio, Finland). The commercial starter concentrate was replaced by barley when the bulls were 4.5 mo old. The grass silage was direct cut from a timothy (Phleum pratense) and meadow fescue (Festuca pratensis) sward and ensiled in bunker silos with a formic acid-based additive applied at a rate of $5 \mathrm{~L} /$ tonne. No medications were used in any of the feeds.

\section{Procedures and Chemical Analyses}

The treatment of the calves was approved by the local ethical animal experiment committee. The postweaning growth period lasted $112 \mathrm{~d}$ until the bulls were 6 mo old. Health parameters such as fecal consistency (normal or diarrhea), bloat, and hair loss, were monitored daily. Daily feed intake was measured penwise (i.e., average for 5 calves). The calves were weighed on 2 consecutive days at the start of the experiments and every $14 \mathrm{~d}$ thereafter (always before morning feeding) during the preweaning phase. During the postweaning phase, the animals were weighed every $28 \mathrm{~d}$. Thus, only BW was measured and no wither and hip heights were measured. Milk replacer, concentrate, and silage subsamples for chemical analyses were taken daily and pooled over periods of $2 \mathrm{wk}$ for grass silage and $4 \mathrm{wk}$ for concentrate and milk replacers. Samples were stored frozen at $-20^{\circ} \mathrm{C}$ before analyses. The chemical analyses of feed samples (except the fatty acid composition of fats) were conducted as described by Ahvenjärvi et al. (2000). The fatty acid compositions of fats in the milk replacers were determined according to Kankaanpää et al. (2001), except that the column used was $120 \mathrm{~m} \times 0.25 \mathrm{~mm}$ (i.d.) silica capillary with $0.20 \mu \mathrm{m}$ AT-2335 cyanosilicone phase (Alltech Associates Inc., Deerfield, IL). In addition, peak area percentages of fatty acid methyl esters were converted to fatty acid percentages (of total fatty acids) using correction factors determined by analyzing a certified reference milk fat (BCR-CRM 164) in the 
same sample set. Silage samples were analyzed for water-soluble carbohydrates, lactic and formic acids, VFA, soluble and ammonia $\mathrm{N}$ content of $\mathrm{N}$ by electrometric titration (Moisio and Heikonen, 1989), and for digestible OM in DM (D-value) by near-infrared spectroscopy as described by Nousiainen et al. (2004).

An additional 12 Ayrshire bull calves that averaged $15 \mathrm{~d}$ of age and BW of 49.9 (SE 0.9) $\mathrm{kg}$ were purchased from local farms for measuring the in vivo digestibility of the experimental diets. The feeding of the calves was similar to that in experiments 1 and 2 during preweaning. Two 4-d total fecal collection periods for each animal were conducted when the calves were between 4 and $7 \mathrm{wk}$ old and had an average BW of $70.1 \mathrm{~kg}$ (SE $1.2 \mathrm{~kg})$. The animals were placed in individual pens $(1.2 \times 1.2 \mathrm{~m})$, and their feed consumptions and fecal excretions were measured individually every day. Feed and fecal samples were collected daily. Feed samples were pooled over collection periods and stored frozen at $-20^{\circ} \mathrm{C}$ before analyses. Fecal samples were pooled for each calf over both periods and stored frozen at $-20^{\circ} \mathrm{C}$ before analyses. The samples were analyzed as described above.

\section{Calculations and Statistical Methods}

The ME value of silage was calculated as $0.16 \times \mathrm{D}$ value (MAFF, 1975, 1981). The ME values of concentrates and milk replacers were calculated as described by Schiemann et al. (1972) and MAFF (1975, 1984). The results are shown as least squares means over the 2 experiments because the records from 2 excluded animals on the VO2 diet were not replaced. The animals were weighed on 2 consecutive days at the beginning and end of the experimental periods and the $\mathrm{BW}$ gain of each bull was calculated by difference using the mean of the 2 values. The pen (a group of 5 calves) was used as an experimental unit and thus the mean values for each pen were calculated. There were 4 pens per diet (20 calves each for the lard and VO1 diets and 18 for the VO2 diet). Individual data on 12 calves (4 calves per diet) were used for the digestibility part and the results of the digestibility trial represent the mean of 2 collection periods per calf. The average group feed DMI (CV: postweaning period 6.95; preweaning period 5.93) and growth rate (CV: postweaning period 5.80; preweaning period 5.14), and individual diet digestibility (CV: DM 4.41; OM 4.24; CP 9.12; Fat 12.71) data were subjected to ANOVA using the SAS GLM procedure (Littell et al., 1991). The model was

$$
\begin{aligned}
& \mathrm{y}_{\mathrm{jk}}=\mu+\text { diet }_{\mathrm{j}}+\text { experiment }_{\mathrm{k}} \\
& +\left(\operatorname{diet} \times \text { experiment }_{\mathrm{jk}}+\mathrm{e}_{\mathrm{jk}},\right.
\end{aligned}
$$

where $\mathrm{y}_{\mathrm{jk}}$ is the mean of 5 animals penned together (4 pens/diet); therefore, the used model is a $2 \times 3$ factorial ANOVA.

The model for the digestibility trial was

$$
\begin{aligned}
\mathrm{y}_{\mathrm{ijk}}=\mu & +\operatorname{diet}_{\mathrm{j}}+\operatorname{calf}(\operatorname{diet})_{\mathrm{ij}}+\text { time }_{\mathrm{k}} \\
& +(\text { time } \times \operatorname{diet})_{\mathrm{jk}}+\mathrm{e}_{\mathrm{ijk}},
\end{aligned}
$$

where calf(diet $)_{\mathrm{ij}}$ was used as a error term when comparing diets and $\mathrm{e}_{\mathrm{ijk}}$ when comparing measurement times or measurement time $\times$ diet interaction effects. Differences between the diets were compared using Tukey's $t$-test.

\section{RESULTS}

The average chemical composition and calculated feeding values of the experimental feeds are presented in Table 1 . The CP and fat content of the MR were close to each other. Both the nutritional (high ME contents) and ensiling quality of the grass silages were good in terms of concentrations of fermentation acids and proportions of ammonia $\mathrm{N}$ and soluble $\mathrm{N}$ in total $\mathrm{N}$.

The fatty acid contents of fats in the MR are shown in Table 2. The fat compositions of the vegetable fat mixtures were similar, and contained a lower proportion of C18:0 and a higher proportion of C18:1 compared with lard. The total contents of saturated and unsaturated fatty acids were from 55.0 to $57.7 \%$ and from 41.1 to $42.4 \%$, respectively.

Two calves on VO2 diets were excluded from the study due to several occurrences of bloat, but it was concluded that it was unlikely that the VO2 diet had caused these problems. The other 58 animals remained generally healthy throughout the study after the first 2 wk when there were some incidences of diarrhea (no clear differences in severity) with episodes lasting $2 \mathrm{~d}$ on average. The cost of health treatments was $8.36 € /$ calf. During the preweaning period, some calves $(30 \%$ on the VO1 diet, $35 \%$ on the VO2 diet, $0 \%$ on the lard diet) lost hair from their legs and around the mouth, but no real morbidity problems were observed.

The average feed DM and ME intakes pre- and postweaning are presented in Table 3. During both periods, there were no significant treatment differences in the DMI of any of the feeds. The energy intakes were also quite similar. There was no significant time $\times$ diet interaction effect $(P>0.69)$ for apparent DM, OM, CP, and fat digestibility. The values of apparent DM, OM, CP, and fat digestibility were equally high for all diets preweaning (Table 3 ). The use of vegetable oil mixtures in MR did not cause a higher incidence of diarrhea (days $\%$ of feeding days, there were no clear differences in severity of diarrhea) compared with lard in MR. 
Table 1. Chemical composition ( $/ \mathrm{kg}$ of $\mathrm{DM})$ and feed values $(\mathrm{MJ} / \mathrm{kg}$ of $\mathrm{DM})$ of the milk replacers having different fat sources, starter concentrate, barley, and grass silages.

\begin{tabular}{|c|c|c|c|c|c|c|c|}
\hline & \multicolumn{3}{|c|}{ Fat source ${ }^{1}$} & \multirow[b]{2}{*}{ Concentrate } & \multirow[b]{2}{*}{ Barley } & \multirow{2}{*}{$\begin{array}{l}\text { Silage } \\
\text { Exp. } 1\end{array}$} & \multirow{2}{*}{$\begin{array}{l}\text { Silage } \\
\text { Exp. }\end{array}$} \\
\hline & Lard & VO1 & VO2 & & & & \\
\hline $\mathrm{DM}, \mathrm{g} / \mathrm{kg}$ of feed & 927 & 938 & 930 & 891 & 914 & 221 & 357 \\
\hline $\mathrm{OM}, \mathrm{g} / \mathrm{kg}$ of $\mathrm{DM}$ & 929 & 926 & 926 & 911 & 974 & 931 & 933 \\
\hline $\mathrm{CP}, \mathrm{g} / \mathrm{kg}$ of $\mathrm{DM}$ & 226 & 220 & 236 & 209 & 126 & 159 & 155 \\
\hline Fat, g/kg of DM & 170 & 184 & 179 & 52 & 34 & - & - \\
\hline $\mathrm{NDF}, \mathrm{g} / \mathrm{kg}$ of $\mathrm{DM}$ & - & - & - & 265 & 246 & 595 & 548 \\
\hline $\mathrm{D}$ value ${ }^{2} \mathrm{~g} / \mathrm{kg}$ of $\mathrm{DM}$ & - & - & - & - & - & 700 & 710 \\
\hline $\mathrm{ME},{ }^{3} \mathrm{MJ} / \mathrm{kg}$ of $\mathrm{DM}$ & 15.8 & 15.8 & 15.8 & 12.3 & 13.5 & 11.0 & 11.3 \\
\hline \multicolumn{8}{|l|}{ Fermentation quality of silage } \\
\hline $\mathrm{pH}$ & & & & & & 3.89 & 4.38 \\
\hline VFA, $\mathrm{g} / \mathrm{kg}$ of DM & & & & & & 16 & 3 \\
\hline Lactic + formic acids, $\mathrm{g} / \mathrm{kg}$ of DM & & & & & & 60 & 19 \\
\hline $\mathrm{WSC},{ }^{4} \mathrm{~g} / \mathrm{kg}$ of DM & & & & & & 109 & 120 \\
\hline \multicolumn{8}{|l|}{ In total $\mathrm{N}, \mathrm{g} / \mathrm{kg}$ of $\mathrm{N}$} \\
\hline $\mathrm{NH}_{4} \mathrm{~N}$ & & & & & & 50 & 50 \\
\hline Soluble N & & & & & & 410 & 420 \\
\hline
\end{tabular}

${ }^{1}$ VO1 = Vegetable fat mixture with coconut, palm, and rapeseed oils; VO2 = vegetable fat mixture with coconut and palm oils.

${ }^{2} \mathrm{D}$ value $=$ Digestible $\mathrm{OM}$ in DM.

${ }^{3}$ Metabolizable energy (ME) value of silage was calculated as $0.16 \times \mathrm{D}$ value (MAFF, 1975, 1981); ME values of concentrates and milk replacers were calculated according to Schiemann et al. (1972) and MAFF (1975, 1984).

${ }^{4} \mathrm{WSC}=$ Water-soluble carbohydrates.

The average values for animal performance during the pre- and postweaning phases are shown in Table 4. Only BW was measured and therefore no wither and hip heights are presented; however, the animals were growing normally. The BW curves of the calves and thus weights at the end of the weaning phase and at the age of 6 mo were very similar in all treatments

Table 2. Fatty acid content (\%) of fats in the milk replacers having different fat sources.

\begin{tabular}{lccc}
\hline & \multicolumn{3}{c}{ Fat source $^{1}$} \\
\cline { 2 - 4 } & Lard & VO1 & VO2 \\
\hline C8:0 & - & 1.6 & 1.4 \\
C10:0 & - & 1.3 & 1.2 \\
C12:0 & - & 11.0 & 9.8 \\
C14:0 & 1.7 & 5.3 & 4.5 \\
C16:0 & 30.2 & 34.7 & 32.2 \\
C17:0 & 0.5 & - & - \\
C18:0 & 22.6 & 3.8 & 8.2 \\
Total saturated & 55.0 & 57.7 & 57.3 \\
C16:1 & 1.6 & - & - \\
C17:1 & 0.3 & - & - \\
C18:1 & 26.1 & 32.4 & 34.4 \\
C18:2 & 12.1 & 8.0 & 7.0 \\
C18:3 & 1.2 & 0.7 & 0.1 \\
C20:1 & 0.7 & - & - \\
C20:2 & 0.4 & - & - \\
Total unsaturated & 42.4 & 41.1 & 41.5 \\
Others & 2.6 & 1.2 & 1.2 \\
Total & 100 & 100 & 100 \\
\hline
\end{tabular}

${ }^{1} \mathrm{VO} 1$ = Vegetable fat mixture with coconut, palm, and rapeseed oils; $\mathrm{VO} 2$ = vegetable fat mixture with coconut and palm oils.
(Figure 1). During preweaning, the average daily gain of bulls fed the lard diet was slightly lower (albeit not significantly) compared with the 2 vegetable fat diets. Thus, during the preweaning period, the feed conversion rate in calves given the lard diet was significantly less efficient than that of calves given either the VO1 or the VO2 diet. During the postweaning phase, the feed conversion rate was slightly higher in bulls on the VO2 diet (containing a mixture of palm and coconut oils) compared with the other 2 diets.

\section{DISCUSSION}

Milk fat has commonly been replaced by animal fats, although butterfat has a higher digestibility (an average of 96\%) in MR compared with other fats (Raven, 1970). Until recently, MR have been predominantly manufactured using the cheapest animal fat sources such as lard and tallow. Lard has been reported to have a lower digestibility in MR compared with butterfat (average digestibility of $90 \%$; Raven, 1970). New manufacturing technology enables fats in MR to be composed of various different fatty acid sources combined with animal fats, but there is little information about calf performance if lard is totally replaced by mixtures of vegetable oils. Such information would be valuable due to increased public concern about inclusion of animal fat in calf diets. The present study provides new results on the effects of 2 different solely vegetable oil mixtures 
Table 3. Daily feed intakes $(\mathrm{kg} / \mathrm{d}$ ) during pre- and postweaning (total $\mathrm{n}=58$ bulls), and feed digestion during preweaning (total $\mathrm{n}=12$ bulls).

\begin{tabular}{|c|c|c|c|c|c|}
\hline & \multicolumn{3}{|c|}{ Fat source ${ }^{1}$} & \multirow[b]{2}{*}{ SEM } & \multirow[b]{2}{*}{$P$ value } \\
\hline & Lard & VO1 & VO2 & & \\
\hline \multicolumn{6}{|l|}{ Preweaning (from 0.5 to 2.5 mo old) } \\
\hline Milk replacer, kg/d & 0.58 & 0.59 & 0.59 & - & - \\
\hline Concentrate, kg/d & 0.62 & 0.56 & 0.68 & 0.032 & 0.084 \\
\hline Silage, $\mathrm{kg} / \mathrm{d}$ & 0.15 & 0.11 & 0.12 & 0.014 & 0.207 \\
\hline Total DMI, kg/d & 1.36 & 1.27 & 1.40 & 0.047 & 0.194 \\
\hline ME2 intake, MJ/d & 18.6 & 17.5 & 19.2 & 0.57 & 0.194 \\
\hline \multicolumn{6}{|l|}{ Postweaning (from 2.5 to $6 \mathrm{mo}$ old) } \\
\hline Concentrate, $\mathrm{kg} / \mathrm{d}$ & 2.67 & 2.66 & 2.67 & - & - \\
\hline Silage, $\mathrm{kg} / \mathrm{d}$ & 1.97 & 1.84 & 1.87 & 0.121 & 0.727 \\
\hline Total DMI, kg/d & 4.64 & 4.49 & 4.54 & 0.135 & 0.737 \\
\hline ME intake, MJ/d & 56.1 & 54.4 & 55.0 & 1.51 & 0.738 \\
\hline \multicolumn{6}{|l|}{ Preweaning apparent digestibility } \\
\hline DM & 0.892 & 0.895 & 0.877 & 0.0143 & 0.638 \\
\hline $\mathrm{OM}$ & 0.897 & 0.901 & 0.882 & 0.0148 & 0.614 \\
\hline $\mathrm{CP}$ & 0.825 & 0.794 & 0.800 & 0.0228 & 0.618 \\
\hline Fat & 0.847 & 0.846 & 0.845 & 0.0194 & 0.998 \\
\hline \multicolumn{6}{|l|}{ Preweaning } \\
\hline Diarrhea days, $\%$ of feeding days & 4.20 & 3.13 & 3.13 & 0.685 & 0.486 \\
\hline
\end{tabular}

${ }^{1} \mathrm{VO} 1$ = Vegetable fat mixture with coconut, palm, and rapeseed oils; VO2 = vegetable fat mixture with coconut and palm oils.

${ }^{2} \mathrm{ME}=$ Metabolizable energy.

in MR on calf performance and those results are compared with lard.

The average fat content in the MR was $178 \mathrm{~g} / \mathrm{kg}$ of $\mathrm{DM}$, which represents the recommended fat content for MR (Roy, 1970; Otterby and Linn, 1981). Although the proportion of saturated fatty acids was only slightly lower in lard compared with the 2 vegetable fat mixtures, there was a clear difference in the composition of those saturated fatty acids. The amounts of highly digestible medium-chain fatty acids were higher in vegetable fats compared with the negligible amount in lard.
The proportions and compositions of saturated fatty acids were similar between the VO1 and VO2 diets because the targeted difference between these 2 mixtures was the market price. In the VO1 diet, rapeseed oil (a more expensive component on the market) was included, whereas the VO2 diet used only coconut and palm oils, which represented harder and cheaper fats on the market.

The choice of vegetable fat greatly affects the growth of young preweaned calves. For example, compared with butterfat, growth of calves was similar when tal-

Table 4. Body weights, daily gains, and feed conversion rates during pre- and postweaning ( $\mathrm{n}=58 \mathrm{bulls}$ ).

\begin{tabular}{|c|c|c|c|c|c|}
\hline & \multicolumn{3}{|c|}{ Fat source ${ }^{1}$} & \multirow[b]{2}{*}{ SEM } & \multirow[b]{2}{*}{$P$ value } \\
\hline & Lard & VO1 & $\mathrm{VO} 2$ & & \\
\hline \multicolumn{6}{|l|}{$\mathrm{BW}, \mathrm{kg}$} \\
\hline Initial, $\mathrm{kg}$ at $14 \mathrm{~d}$ & 48.7 & 47.9 & 48.1 & 1.35 & 0.920 \\
\hline At the end of weaning, $\mathrm{kg}$ at $2.5 \mathrm{mo}$ & 88.6 & 89.0 & 91.3 & 1.95 & 0.606 \\
\hline Postweaning at $6 \mathrm{mo}$ & 230.8 & 226.6 & 225.7 & 5.01 & 0.759 \\
\hline \multicolumn{6}{|l|}{ BW gain, g/d } \\
\hline Preweaning (from $14 \mathrm{~d}$ to $2.5 \mathrm{mo}$ ) & 713 & 734 & 771 & 21.5 & 0.226 \\
\hline Postweaning (from 2.5 to $6 \mathrm{mo}$ ) & 1264 & 1223 & 1195 & 31.6 & 0.364 \\
\hline Average gain during the study & 1081 & 1060 & 1054 & 25.3 & 0.752 \\
\hline \multicolumn{6}{|l|}{ Feed conversion rate, $\mathrm{kg}$ of $\mathrm{DMI} / \mathrm{kg}$ of gain } \\
\hline Preweaning (from $14 \mathrm{~d}$ to $2.5 \mathrm{mo}$ ) & $2.09^{\mathrm{a}}$ & $1.77^{\mathrm{b}}$ & $1.84^{\mathrm{b}}$ & 0.043 & 0.005 \\
\hline Postweaning (from 2.5 to $6 \mathrm{mo}$ ) & $3.70^{\mathrm{a}}$ & $3.70^{\mathrm{a}}$ & $3.87^{\mathrm{b}}$ & 0.032 & 0.017 \\
\hline Average feed conversion during the study & $3.33^{\mathrm{ab}}$ & $3.25^{\mathrm{a}}$ & $3.36^{\mathrm{b}}$ & 0.024 & 0.053 \\
\hline
\end{tabular}

${ }^{\mathrm{a}, \mathrm{b}}$ Between-diets comparisons (Tukey, $P<0.05$ ): estimated means with the same letters were not significantly different $(P>0.05)$.

${ }^{1}$ VO1 = Vegetable fat mixture with coconut, palm, and rapeseed oils; VO2 = vegetable fat mixture with coconut and palm oils. 

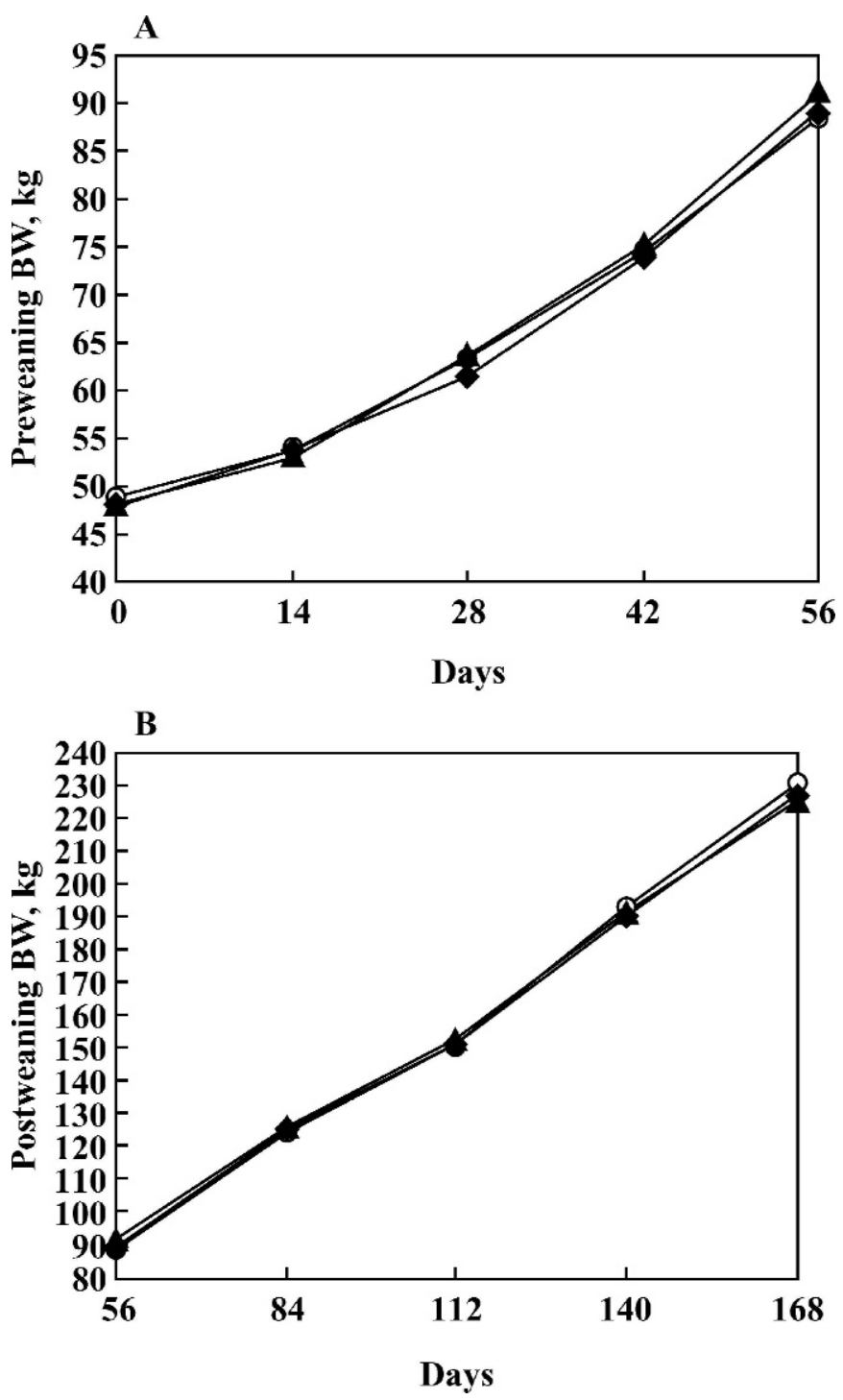

Figure 1. Preweaning (A) and postweaning (B) live weights of calves given diets having either lard $(\bigcirc)$ or 2 mixtures of vegetable fats [VO1 (-) and VO2 ( $)$ ] as fat sources in milk replacers. Mixture VO1 contained palm, coconut, and rapeseed oils; VO2 contained palm and coconut oils.

low and lard were used; inclusion of coconut oil in MR has resulted in good rates of growth, whereas the use of cottonseed, corn, and soybean oils has resulted in poorer growth (Raven, 1970). Jenkins et al. (1985) observed a similar growth response with coconut oil as with tallow, but the calves performed markedly poorer when corn oil was given. In that study, the researchers reported an average daily gain $(\mathrm{kg})$ of 0.533 for tallow and 0.519 for coconut but only $0.392 \mathrm{~kg}$ for corn oil due to the low apparent digestibility of fatty acids in corn oil. In another trial, a corn oil plus tallow diet promoted scours and poor calf gain $(0.31 \mathrm{~kg})$, but a canola oil ( 0.59 $\mathrm{kg}$ ) diet resulted in similar calf performance as tallow $(0.61 \mathrm{~kg})$ (Jenkins et al., 1986).

In the present study, calves on the VO2 diet performed well, as was reported previously when calves were given a MR including either coconut (Jenkins et al., 1985) or palm oil (O'Brien et al., 2003). Theoretically, the inclusion of rapeseed oil might impair performance due to the higher amount of unsaturated fatty acids compared with coconut oil and palm oil. In the present study, the fatty acid composition of the fat in the VO1 diet was similar to that of the fat in the VO2 diet, which explained the equal daily gain of calves on those 2 diets. The present results support the unexpected good calf performances reported by Jenkins et al. (1986), when rapeseed oil was tested against tallow as a fat source in MR. During the 1970s, in contrast to the results of the present study and those of Jenkins et al. (1986), partial replacement of lard by rapeseed oil was found to impair fat digestibility. This was attributed to the rapeseed oil having a high content of erucic acid, which has extremely low digestibility (29.6\%; Bell and Adams, 1974). The low erucic acid content of rapeseed oil from current rape varieties (below 1\%; Tuori, 1992 ) and less than $2 \%$ in the oil used by Jenkins et al. (1986) evidently explained the good performances observed in these 2 studies. To our knowledge, no direct comparisons concerning fat digestibility between low erucic acid rapeseed oil and lard exist in the literature.

It is known that if MR is not digested almost as efficiently as whole milk the risk of diarrhea will increase (Raven, 1970; Stobo, 1983). Raven (1970) reported mean digestibility of $96 \%$ for butterfat, $90 \%$ for lard, $89 \%$ for palm oil, and $94 \%$ for coconut oil. More recently, Spanski et al. (1997) reported, in calves fed lard triglycerides, an apparent digestibility of $79 \%$ for the total fatty acids. In the present study, the apparent digestibility of fats for the whole diet was lower (an average value of $84.6 \%$ ) than that reported for butterfat (Raven, 1970). The digestibility of fatty acids in calves has been shown to increase with a reduction in chain length (Raven, 1970). Although there were marked differences in the fatty acid composition between the vegetable fat mixtures (VO1 and VO2) and lard (Table 2), no difference was detected in the apparent fat digestibility of the diets. Evidently, the true fat digestibility is higher than the apparent value because of endogenous and metabolic fecal fat loss. According to Roy (1970), the fecal fat loss was $50 \mathrm{mg} / \mathrm{kg}$ of BW in veal calves on a milk-only diet. The true digestibility and metabolic fecal loss may be estimated by the Lucas principle (Van Soest, 1994). Applying this principle to the data (averages over treatments) from the first digestibility trial of the present study, the following equation was obtained: digestible fat $(\mathrm{g} / \mathrm{kg}$ of $\mathrm{DM})=0.95 \times$ fat $(\mathrm{g} / \mathrm{kg}$ of $\mathrm{DM})-$ 
11. This means that the true fat digestibility is $95 \%$ and the metabolic fecal fat loss is $11 \mathrm{~g} / \mathrm{kg}$ of fat digested. The estimate for metabolic loss (about $90 \mathrm{mg} / \mathrm{kg}$ of BW) is higher than that reported by Roy (1970), probably because the calves were fed both milk replacers and dry feed.

Before weaning, the feed conversion rate was higher and BW gain somewhat lower in calves fed the lard diet compared with the vegetable oil diets. The ME intake or number of diarrhea days did not explain the difference in animal performance. The lower proportion of medium-chain fatty acids and higher proportion of C18:0 fatty acid in the lard diet compared with the other diets may have contributed to these differences. After weaning, the average daily gain of dairy-breed bulls on all diets was good (1227 g), showing that feeding a mixture of solely vegetable oils for calves during preweaning did not affect postweaning growth in the present study.

In conclusion, the similar daily gains during the preweaning period from 0.5 to 2.5 mo showed that, nutritionally, both lard and vegetable fat mixtures were equally suitable fat sources in MR in the present study conditions. This demonstrated the possibility of feeding young calves a diet including MR containing 2 different solely vegetable oil mixtures. The good postweaning daily gain of dairy bull calves until 6 mo of age was not compromised by the use of diets containing vegetable fats in MR in early life.

\section{ACKNOWLEDGMENTS}

This study was partially funded by the Ministry of Agriculture and Forestry, and Valio Ltd. The authors would like to thank the staff, Pirkko Kainulainen, Riikka Keränen, Matti Huumonen, Sami Torvinen, and Olavi Jokipii, of the North Ostrobothnia Research Station in Ruukki, for technical assistance and care of experimental animals. The assistance of the staff at Animal Production Research in Jokioinen in conducting laboratory analyses is also acknowledged.

\section{REFERENCES}

Ahvenjärvi, S., A. Vanhatalo, P. Huhtanen, and T. Varvikko. 2000. Determination of reticulo-rumen and whole stomach digestion in lactating cows by omasal canal and duodenal sampling. Br. J. Nutr. 83:67-77.

Bell, J. M., and S. C. M. Adams. 1974. Digestibility of milk replacers containing rapeseed oil, fed to dairy calves under a month old. Can. J. Anim. Sci. 54:331-335.
Graulet, B., D. Gruffat-Mounty, D. Durand, and D. Bauchart. 2000. Effects of milk diets containing beef tallow or coconut oil on the fatty acid metabolism of liver slices from preruminant calves. Br. J. Nutr. 84:309-318

Heinrichs, A. J., S. J. Wells, and W. C. Losinger. 1995. A study of the use of milk replacers for dairy calves in the United States. J. Dairy Sci. 78:2831-2837.

Jenkins, K. J. 1988. Factors affecting poor performance and scours in preruminant calves fed corn oil. J. Dairy Sci. 71:3013-3020.

Jenkins, K. J., J. K. G. Kramer, and D. B. Emmons. 1986. Effect of lipids in milk replacers on calf performance and lipids in blood plasma, liver, and perirenal fat. J. Dairy Sci. 69:447-459.

Jenkins, K. J., J. K. G. Kramer, F. D. Sauer, and D. B. Emmons. 1985 Influence of triglycerides and free fatty acids in milk replacers on calf performance, blood plasma, and adipose lipids. J. Dairy Sci. 68:669-680.

Kankaanpää, P., K. Nurmela, A. Erkkilä, M. Kalliomäki, D. Holmberg-Marttila, S. Salminen, and E. Isolauri. 2001. Polyunsaturated fatty acids in maternal diet, breast milk and serum lipid fatty acids of infants in relation to atopy. Allergy 56:633-638.

Littell, R. C., R. J. Freund, and P. C. Spector. 1991. SAS System for Linear Models. SAS Inst., Inc., Cary, NC.

Ministry of Agriculture, Fisheries and Food (MAFF). 1975. Energy Allowances and Feeding Systems for Ruminants. Technical Bulletin 33. Her Majesty's Stationary Office, London.

Ministry of Agriculture, Fisheries and Food (MAFF). 1981. Animal Science 1979. ADAS Agricultural Science Service, Research and Developments Reports. Reference book 254. Her Majesty's Stationery Office, London, UK.

Ministry of Agriculture, Fisheries and Food (MAFF). 1984. Energy Allowances and Feeding Systems for Ruminants. Reference Book 433. Her Majesty's Stationary Office, London, UK.

Moisio, T., and M. Heikonen. 1989. A titration method for silage assessment. Anim. Feed Sci. Technol. 22:341-353.

Nousiainen, J., S. Ahvenjärvi, M. Rinne, M. Hellämäki, and P. Huhtanen. 2004. Prediction of indigestible cell wall fraction of grass silage by near infrared reflectance spectroscopy. Anim. Feed Sci. Technol. 115:295-311.

O'Brien, M. L., K. J. Touchette, J. A. Coalson, and R. M. Costello. 2003. Inclusion of vegetable fats in calf milk replacers. J. Dairy Sci. 86(Suppl. 1):21. (Abstr.)

Otterby, D. E., and J. G. Linn. 1981. Advances in nutrition and management of calves and heifers. J. Dairy Sci. 64:1365-1377.

Raven, A. M. 1970. Fat in milk replacers for calves. J. Sci. Food Agric. 21:352-359.

Roy, J. H. B. 1970. The Calf: Nutrition and Health, 3rd ed. London Iliffe Books Ltd., London, UK

Schiemann, R., K. Nehring, L. Hoffmann, W. Jentsch, and A. Chudy. 1972. Energetische Futterbewertung und Energienormen. VEB Deutcher Landwirtschafsverlag Berlin, Germany.

Spanski, N. A., J. K. Drackley, C. L. Davis, and E. H. Jaster. 1997. Utilization of supplemental triglycerides or free fatty acids by calves from 4 to 10 weeks of age. J. Dairy Sci. 80:573-585.

Stobo, I. J. F. 1983. Milk replacers for calves. Pages 113-140 in Recent Advances in Animal Nutrition (Proc. Ann. Nutr. Conf. Feed Manufacturers, Univ. of Nottingham, UK). W. Haresign, ed. Butterworth \& Co. Publ., Ltd., London, UK.

Tuori, M. 1992. Rapeseed meal as a supplementary protein for dairy cows on grass silage-based diet, with the emphasis on the Nordic AAT-PBV feed protein evaluation system. Agric. Sci. Finl. 1:369-439.

Van Soest, P. 1994. Nutritional Ecology of the Ruminant. 2nd ed. Cornell Univ. Press, Ithaca, NY. 